\title{
REVIEW
}

\section{IMMUNOACTIVATION AND IMMUNOPATHOGENY DURING ACTIVE VISCERAL LEISHMANIASIS}

\author{
Hiro GOTO(1,2) \& Maria das Graças PRIANTI(1)
}

\begin{abstract}
SUMMARY
Visceral leishmaniasis is caused by protozoan parasites of the Leishmania donovani complex. During active disease in humans, high levels of IFN- $\gamma$ and TNF- $\alpha$ detected in blood serum, and high expression of IFN- $\gamma$ mRNA in samples of the lymphoid organs suggest that the immune system is highly activated. However, studies using peripheral blood mononuclear cells have found immunosuppression specific to Leishmania antigens; this poor immune response probably results from Leishmania antigen-engaged lymphocytes being trapped in the lymphoid organs. To allow the parasites to multiply, deactivating cytokines IL-10 and TGF- $\beta$ may be acting on macrophages as well as anti-Leishmania antibodies that opsonize amastigotes and induce IL-10 production in macrophages. These high activation and deactivation processes are likely to occur mainly in the spleen and liver and can be confirmed through the examination of organ samples. However, an analysis of sequential data from studies of visceral leishmaniasis in hamsters suggests that factors outside of the immune system are responsible for the early inactivation of inducible nitric oxide synthase, which occurs before the expression of deactivating cytokines. In active visceral leishmaniasis, the immune system actively participates in non-lymphoid organ lesioning. While current views only consider immunocomplex deposition, macrophages, $\mathrm{T}$ cells, cytokines, and immunoglobulins by diverse mechanism also play important roles in the pathogenesis.
\end{abstract}

KEYWORDS: Visceral leishmaniasis; Human; Immunosuppression; Immunoactivation; Cytokines; Immunopathogenesis.

Visceral leishmaniasis is caused by protozoa of the genus Leishmania that are transmitted to mammalian hosts, including humans, by phlebotomine sandflies. The disease is present in 66 countries in tropical and subtropical regions, and $90 \%$ of cases occur in India, Sudan, Bangladesh, Nepal, and Brazil. It is estimated that there are 500,000 new cases a year worldwide ${ }^{68}$, and 3,000 new cases occur each year in $\mathrm{Brazil}^{48}$. Until recently, the disease was thought to be caused by three species of the Leishmania donovani complex: Leishmania (Leishmania) donovani, L. (L.) infantum, and Leishmania (L.) chagasi (a species present in Brazil). There is now debate, however, over whether $L$. $(L)$. infantum and Leishmania (L.) chagasi are the same ${ }^{44}$ or different ${ }^{60}$ species. In this review, the names of the three species will be used as in the original publications. Leishmania (Leishmania) donovani is present in East Africa, India, and parts of the Middle East, while L. (L.) infantum in Europe, North Africa, and South and Central America. Human infections can be asymptomatic or can manifest as oligosymptomatic and progressive diseases; progressive cases can involve hepatosplenomegaly, fever, pancytopenia, hypergammaglobulinemia, and serious weight $\operatorname{loss}^{4}$. During active visceral leishmaniasis, the parasite multiplies within the cells of the mononuclear phagocyte system in the spleen, liver, and bone marrow, and the disease is fatal if untreated.
Studies in experimental models using Leishmania major in inbred mouse strains suggest that protection from the disease comes from the Th1-type immune response that is initiated when interleukin (IL)-12 acts on antigen-presenting cells, triggering Th1 CD4 ${ }^{+} \mathrm{T}$ cells to produce interferon-gamma (IFN- $\gamma$ ) and tumor necrosis factor alpha (TNF- $\alpha$ ). Susceptibility to the disease is attributed to the Th2-type immune response and the production of IL-4 and IL-13 $3^{56}$. This dichotomy is not as clear in models of visceral leishmaniasis in mice caused by Leishmania donovani. Studies have found differences between these models and those of cutaneous leishmaniasis. $\mathrm{CD}^{+}$and $\mathrm{CD}^{+} \mathrm{T}$ cells are important for resistance to visceral leishmaniasis, and they are involved in the production of IL-2, IFN- $\gamma$, and IL-12. The latter acts independently of IFN- $\gamma$ and is linked to the production of transforming growth factor beta (TGF- $\beta$ ). Susceptibility involves IL-10 (but not IL-4) and B cells ${ }^{30}$.

Because the immune response is severely affected during active visceral leishmaniasis, few studies have examined immune protective mechanisms in humans. Although immune protective mechanisms play a crucial role in resistance, some studies suggest that the development of the disease among infected people depends on factors outside of the immune system ${ }^{18}$ that have not yet been defined. A small proportion of

Work published as part of the celebration of the $50^{\text {th }}$ anniversary of the São Paulo Institute of Tropical Medicine (1959/2009).

(1) Laboratory of Seroepidemiology and Immunobiology, Instituto de Medicina Tropical de São Paulo, Universidade de São Paulo, SP, Brazil.

(2) Department of Preventive Medicine, Faculdade de Medicina da Universidade de São Paulo, SP, Brazil.

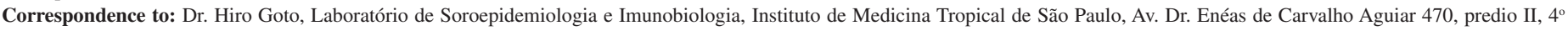
andar, 05403-000 São Paulo, SP, Brasil. Tel: + 55-11-3061-7023, Fax: + 55-11-3061-8270, E-mail: hgoto@usp.br 
infected individuals develop the active disease, which is accompanied by considerable disturbance in the immune response. This review discusses alterations in immune response during the active disease, as well as the participation of immune elements in the lesions of non-lymphoid organs.

\section{IMMUNOACTIVATION IN LYMPHOID ORGANS}

Current view on alterations of the immune response during active visceral leishmaniasis refers to immunosuppression mostly specific to Leishmania antigens; tests for delayed-type hypersensitivity to these antigens (the Leishmanin or Montenegro tests) have been negative, and there is no Leishmania antigen-induced proliferative response of the peripheral blood mononuclear cells (PBMC) $)^{13,33,34,42}$. Some studies show that the lymphoproliferative response to mitogens is also affected ${ }^{14,29,34}$ but it is primarily the Leishmania antigen-driven response that is disturbed. In addition, IL-12 is absent in Leishmania antigen-induced cytokine production in PBMC culture supernatant ${ }^{28}$, and IL- 2 and IFN- $\gamma$ are either absent or present in low levels ${ }^{12,15,28,39}$. These findings reinforce the view that it is mainly the Th1 response that is suppressed.

This understanding of immunosuppression, however, does not reflect other alterations of immune response that occur during active disease. Although some studies evaluating cytokines in serum samples have either not detected or found low concentrations of IFN- $\gamma^{63,69,70}$, other studies have produced conflicting results. IFN- $\gamma$ was detected in 17 of 44 patients in Iran $^{2}$ and in 13 of 15 patients in Brazill ${ }^{20}$; in addition, high levels have been confirmed in patients in Asia, Europe, Africa, and Brazil 9,15,31,32,50,52. These differing results are most likely not related to the selected patient groups or to the Leishmania species involved, but rather to the samples that were analyzed. Two studies, for example, examined IFN- $\gamma$ levels in both the supernatant of Leishmania antigen-induced PBMCs and the serum; low levels were found in the first sample, while high levels were found in the second sample $\mathrm{e}^{9,15}$. TNF- $\alpha$, another cytokine important for protection, was also found at elevated levels in the serum ${ }^{20,70}$.

IFN- $\gamma$ in the serum most likely comes from the lymphoid organs where Leishmania proliferates. There is little data directly supporting this view, however, since it is difficult to obtain tissue samples from patients with the active disease. However, IFN- $\gamma$ mRNA expression is, as expected, present and high in bone marrow ${ }^{36}$, lymph node ${ }^{27}$, and spleen $^{38,50}$ aspirates.

These data suggest that during active visceral leishmaniasis the immune system is not suppressed, but is highly activated. This activation is most likely induced by Leishmania antigens and may occur mainly in the organs where the parasites thrive (such as the spleen, liver, and bone marrow) where the cells engaged in Leishmania antigen-induced immune response are probably trapped. Therefore, PBMCs would consist of a non-Leishmania antigen-specific population, which would fail to proliferate or produce cytokines upon Leishmania antigen stimulation. It is also possible that the PBMCs are pre-activated and cannot be further stimulated; this is less likely, however, since a study in Ethiopia compared individuals with active disease, cured disease, subclinical manifestations, asymptomatic disease, and no disease and found that memory $\left(\mathrm{CD} 45 \mathrm{RO}^{+} \mathrm{CD} 27^{+}\right) \mathrm{CD}^{+}$cells and naïve $\left(\mathrm{CD} 45 \mathrm{RO}^{-} \mathrm{CD} 27^{+}\right)$ $\mathrm{CD}^{+}$cells were at their lowest levels in patients with the active disease ${ }^{31}$. Furthermore, the same study found that phorphol miristate acetate- and ionomycin-induced $\mathrm{CD}^{+}$and $\mathrm{CD}^{+}$cell IFN- $\gamma$ production was at its lowest level in patients with the active disease ${ }^{31}$.

It is important to point out that the known polyclonal activation of $\mathrm{B}$ cells in visceral leishmaniasis ${ }^{25}$ is probably also a part of this general activation of the immune system.

We observed that even though the immune system is highly activated and the main leishmanicidal cytokines IFN- $\gamma$ and TNF- $\alpha$ are produced, the parasitic infection still progresses. This indicates the existence of deactivating mechanisms that probably act on macrophages and allow Leishmania to multiply. Studies of PBMCs have suggested a variety of general suppressive mechanisms, including soluble factors ${ }^{5}$, different cells $^{10}$, and the interactions of cytokines ${ }^{3}$; these studies do not, however, explain the progressive proliferation of parasites within macrophages in lymphoid organs during active visceral leishmaniasis.

The role of cytokine interaction in suppression has been extensively explored and may better explain the progressive infection. Because it plays an important role in susceptibility to Leishmania major-induced cutaneous leishmaniasis ${ }^{56}$, levels of IL-4 have been examined in cases of human visceral leishmaniasis. The level of IL-4 in serum varies, and IL-4 was detected in some patients ${ }^{20,50,63,69}$ but not in others ${ }^{2,15,52}$. IL-4 mRNA expression was detected in bone marrow in approximately half of the cases ${ }^{38}$. IL-13, which is also related to susceptibility, was detected in serum in some studies ${ }^{2,50}$.

Another cytokine, IL-10, has been identified in experimental studies of cutaneous leishmaniasis as an important cytokine not only for susceptibility, but also for the persistence of the parasite in lesions ${ }^{7}$. It has also been found to be important in susceptibility to visceral leishmaniasis ${ }^{30,49}$. It has been detected in different samples of human visceral leishmaniasis: as mRNA in bone marrow ${ }^{36}$, lymph node $^{27}$, and spleen $^{38}$ aspirates and at high levels in serum ${ }^{1,2,15,40,50,52,63,69}$; for further information $\mathrm{se}^{51}$. As mentioned earlier, the possible effect of IL-10 on the production of, or proliferation of IFN- $\gamma$ producing cells ${ }^{11,28}$ may not be important given the high activation of the immune response in lymphoid organs during active disease. Rather, the effect seen with IL-10 from patient plasma on macrophages that allowed better parasite growth ${ }^{50}$ should be considered important to the development of the disease.

Transforming Growth Factor- $\beta$ (TGF- $\beta$ ) is also important in leishmaniasis. High levels of total TGF- $\beta$ were detected in sera in one study ${ }^{9}$ and levels similar to those in control individuals were detected in another ; TGF- $\beta$ was also found to be highly expressed in bone marrow ${ }^{26}$ and spleen ${ }^{50}$ samples. Its macrophage deactivating effect was observed both in vitro and in vivo ${ }^{6}$ and was found to affect NO production ${ }^{41}$.

Most of the activation and deactivation of the immune response during active visceral leishmaniasis should take place in the spleen and the liver. However, while Leishmania multiplies in these lymphoid organs, little is known about cell and cytokine interactions in these organs in humans. It is important to understand these interactions in order to develop treatments and vaccines.

In the only published study analyzing cell populations and cytokine expression in human spleens ${ }^{50}$, the spleen aspirate was composed of $70 \%$ lymphocytes, $4 \%$ plasma cells, $7 \%$ monocytes/macrophages, and $10 \%$ neutrophils, with frequent blasts. Gated lymphocyte subsets that 
also included some $\mathrm{CD} 14^{+}$monocytes were analyzed, and B $\left(\mathrm{CD} 19^{+}\right)$ cells were present in a slightly smaller proportion than $\mathrm{T}\left(\mathrm{CD}^{+}\right)$cells. Cytokine mRNA expression in these cells showed the presence of IL-10, IFN- $\gamma$, IL-4, TNF- $\alpha$, and TGF- $\beta$. With specific treatment, the relatively high expression of IL-10, IFN- $\gamma$, and TGB- $\beta$ decreased significantly. IL10 and IFN- $\gamma$ expression was mainly in $\mathrm{CD}^{+}$cells, and in the remained cell population after the depletion of $\mathrm{CD}^{+}, \mathrm{CD} 19$, and $\mathrm{CD} 25^{+}$cells; IL-10 in particular was not significantly expressed in $\mathrm{CD} 4^{+} \mathrm{CD} 25^{+}$ (Foxp3) regulatory cells. These findings reinforce the view that most of the activation and deactivation of the immune response takes place in lymphoid organs and that IFN- $\gamma$ and TNF- $\alpha$ are activating cytokines, while IL-10 and TGF- $\beta$ are deactivating cytokines.

However, in the previously mentioned study, red pulp was apparently underrepresented in the spleen aspirate samples since the macrophages were present in small proportion; hyperplasia and hypertrophy of macrophages in the red pulp where parasites proliferate are known to be the dominant features of active visceral leishmaniasis ${ }^{67}$. It is likely that in active disease the deactivation of macrophages would take place in this area, but this issue should be better analyzed. A study of visceral leishmaniasis in mice contributes to our understanding of these interactions ${ }^{46}$. During the infection's progression, the number of T and dendritic cells increased in the periarteriolar lymphoid sheath and marginal zone; at the same time, parasite proliferation in macrophages was occurring elsewhere, in the red pulp. The prominent production of IL-10 in the marginal zone and TGF- $\beta$ in the red pulp was observed. The cytokines in these locations may play a role in the progression of the infection. While the emphasis in the literature has been on IL-10, these experimental data indicate that TGF- $\beta$ must be better understood. In another study of experimental visceral leishmaniasis, the effect of a high TNF- $\alpha$ disorganizing marginal zone of white pulp was also found to be important to the progression of the infection ${ }^{37}$.

The only study of the liver of human visceral leishmaniasis patients was restricted to cases with a nodular pattern. This pattern of liver pathology is generally present in cases or disease phases where the host's protective response is present. The study examined nine cases, and some elements were semi-quantified in tissues subjected to immunohistochemistry ${ }^{59}$. Within the nodules, Leishmania amastigotes were present, along with IFN- $\gamma$ and TNF- $\alpha$ and few IL-10 producing cells. In addition to T, B, and NK cells, high numbers of plasma cells were also present. A considerable amount of TGF- $\beta$ was detected but not quantified. Although the study was restricted to cases with a nodular pattern, the data again show the simultaneous presence of macrophage activating and deactivating cytokines; the smaller presence of the latter may be due to the selection criteria of the cases.

While anti-Leishmania antibodies have no protective role in leishmaniasis, some data suggest that they favor parasite growth. Mutant mice that are lacking mature B cells, for example, have an increased resistance to Leishmania donovani ${ }^{61}$. Furthermore, cutaneous lesion-derived amastigotes were shown to be coated by $\mathrm{IgG}$, and when phagocytized by macrophages, they induced IL-10 production in vitro and favored parasite growth ${ }^{35}$. Similarly, IgG-free axenic L. chagasiinfected human monocytes do not produce IL-10, but high levels of IL10 are observed within cells when amastigotes incubated with visceral leishmaniasis sera were used ${ }^{47}$. The same researchers have examined individuals living in areas where visceral leishmaniasis is endemic. They have found a negative correlation between anti-Leishmania antibody levels and delayed-type hypersensitivity induration size, and have found a positive correlation between high antibody levels and active disease $^{47}$. This antibody-dependent mechanism may operate in the red pulp of the spleen or in the inflammatory foci of the liver, where plasma cells are multiplying, producing antibodies, and contributing to parasite multiplication.

Although these fractional data from human samples allow us to infer some of the mechanisms at work in the progression of the infection, experimental models would supply more extensive information. Recent observations of hamsters, for example, have highlighted important information $^{45}$. In visceral leishmaniasis in hamsters, where the disease manifests similarly to in humans, parasites continued to replicate in the spleen, liver, and bone marrow, and IL-2, IFN- $\gamma$, and TNF/lymphotoxin were detected in these organs. However, inducible nitric oxide (NO) synthase mRNA or synthase activity was not detected in either the liver or spleen. No explanation for this finding was offered. There was no expression of IL-4 mRNA, and the expression of IL-10 mRNA occurred late in the disease's progression, while the inactivation of NO synthase was present from the beginning. While TGF- $\beta$ mRNA expression in the spleen was not very high, the active form of TGF- $\beta$ increased but also occurred late in the disease's progression. This discrepancy between TGF- $\beta$ mRNA expression and active TGF- $\beta$ may be due to the presence of cathepsin B in L. donovani and L. chagasi. These species have a cathepsin B-like gene that plays a role in the growth of parasites within macrophages, and the cathepsin $\mathrm{B}$ protein has the ability to directly activate TGF- $\beta^{62}$. Another finding from this study, the decreased expression or inactivation of inducible NO synthase, may be caused by the arginase activation of Leishmania, which may lead to an alternative activation of the macrophages. We raise this hypothesis since we observed the activation of arginase of L. amazonensis and infected macrophages in the presence of insulin-like growth factor- $\mathrm{I}^{66}$, which is present in the various tissues.

In active visceral leishmaniasis, the immune system is highly activated and produces both the macrophage-activating cytokines IFN- $\gamma$ and TNF- $\alpha$ and the macrophage-deactivating cytokines IL-10 and TGF- $\beta$. However, recent experimental data suggest that parasitic factors are also important. Cathepsin B, for example, directly activates TGF- $\beta$, and parasitic arginase is activated by a non-specific host factor (insulin-like growth factor-I), which activates the macrophages and inhibits inducible NO and NO production. Furthermore, these parasitedependent factors and non-specific host factors may play more of a role in the development of the active disease in areas where it is endemic. While the study of genetic susceptibility is currently focused on genes related to the immune system, it should be expanded to examine genes outside of the immune system.

\section{IMMUNOPATHOGENY IN NON-LYMPHOID ORGANS}

During infection organs outside of the mononuclear phagocyte system are also affected ${ }^{23}$. In these other organs, mononuclear cell inflammatory infiltrate appears in the presence of few Leishmania antigens; this appearance suggests that immune mechanisms play a role in lesioning. Studies of lungs have observed multifocal interstitial pneumonitis, a process that is driven by Leishmania antigens ${ }^{21}$ and the participation of immune elements. Recently, the inflammatory process constituted by 
mononuclear cells was characterized, and shown to be constituted by macrophages and $\mathrm{CD}^{+} \mathrm{T}$ cells. The expressions of IL-4 and TNF- $\alpha$ were high when compared to normal lungs ${ }^{64}$. In hamsters with visceral leishmaniasis, a transient $\mathrm{IgG}$ deposit was observed in the capillary walls of the lungs; it increased in intensity until day 30 of the infection and then declined. There were no significant $\mathrm{C} 3 \mathrm{~b}$ deposits at any time ${ }^{43}$, which suggests that a mechanism other than immune complex deposition was at work. The time course of various elements and their interactions must be better studied.

The kidney is by far the best studied organ, and there have been several studies of renal alterations in human visceral leishmaniasis ${ }^{22,24}$. Dogs and hamsters with visceral leishmaniasis presenting lesions similar to those in humans are used as models to understand human pathology $y^{16,57}$. Until recently, studies of glomerular alterations in visceral leishmaniasis pathogenesis have only found immune complex deposition ${ }^{19,53,58}$. However, since other studies of glomerulonephritis pathogenesis of other etiologies have revealed the involvement of $\mathrm{T}$ cells $^{65}$ and adhesion molecules ${ }^{8}$ we extended our study to evaluate the participation of other immune elements. We detected $\mathrm{CD}^{+}{ }^{+} \mathrm{T}$ cells in the glomeruli of five dogs with naturally acquired visceral leishmaniasis from an area where the disease is endemic ${ }^{17}$. Furthermore, in a parallel study we identified glomerulonephritis in 55 dogs naturally infected with visceral leishmaniasis, characterized their glomerular alterations histopathologically, and classified them into six different patterns (proliferative patterns were most common) ${ }^{16}$. Both studies strongly suggested that the migration and proliferation of cells, including $\mathrm{T}$ cells, plays a role in the pathogenesis of glomerulonephritis in visceral leishmaniasis. Other immune elements were later analyzed (COSTA et al., submitted), and we observed the Leishmania antigen in glomeruli cells in $98 \%$ of animals; $\mathrm{CD}^{+} \mathrm{T}$ cells were observed in the glomeruli of most animals, $\mathrm{CD}^{+} \mathrm{T}$ cells were observed to a lesser extent, and no $\mathrm{T}$ cells were observed in non-infected controls. Deposits of immunoglobulin and C3b did not differ between infected animals and non-infected controls, which suggests that they play no significant role in these animals due to chronic evolution. Since a proliferative marker Ki-67 was not locally detected, $\mathrm{CD}^{+} \mathrm{T}$ cells may have migrated into the glomeruli, with contribution of adhesion molecules and the diminished apoptosis of cells maintaining the proliferative pattern of glomerulonephritis in visceral leishmaniasis.

We are currently using experimental models of visceral leishmaniasis to examine the time course and interplay of various immune elements in the pathogenesis of glomerulonephritis. Models in mice do not reproduce the progressive visceral leishmaniasis of humans but in this species reagents for different markers are easily available. We recently described the mouse model in depth and showed that it is useful to the study of the pathogenesis of glomerulonephritis ${ }^{54}$. Initial studies in this model show the early proliferation of macrophage/phagocytes in glomeruli and the presence of mainly $\mathrm{CD}^{+} \mathrm{T}$ cells; these findings correspond to our observations of canine visceral leishmaniasis ${ }^{55}$.

All of the data from animal models and from the lungs and kidneys of visceral leishmaniasis patients show that immune elements play an active role in lesioning; these elements include immunoglobulins, macrophages, $\mathrm{T}$ cells, and certain cytokines. Immunocomplex deposits may occur in certain cases, but immunoglobulins appear to participate both transiently and through alternative mechanisms that are not yet clear.

\section{CONCLUDING REMARKS}

While it is often assumed that immunosuppression occurs during active visceral leishmaniasis in humans, the immune system is in fact highly activated and produces macrophage-activating cytokines such as IFN- $\gamma$ and TNF- $\alpha$ as well as macrophage-deactivating cytokines such as IL-10 and TGF- $\beta$. These high activation and deactivation processes are likely to occur mainly in the spleen and liver, and it is likely that peripheral blood mononuclear cells respond poorly to Leishmania antigens because antigenengaged lymphocytes are trapped in the lymphoid organs. To understand the process of infection and disease, it is important to analyze the lymphoid organs. Studies must examine the regions that involve amastigote-harboring macrophages and the localization of various immune elements.

Data from animal models of visceral leishmaniasis must be critically and carefully analyzed if they are to guide observations in humans. Since there are many unanswered questions about the factors that lead to disease development in infected people, the role of parasite-related and non-specific host factors must be taken seriously.

In active visceral leishmaniasis, the immune system actively participates in non-lymphoid organ lesioning. Further studies are needed to identify the mechanisms through which macrophages, T cells, cytokines, and immunoglobulins participate in pathogenesis.

Studies of immune activating and deactivating processes as well as immunopathogenic mechanisms may contribute to the better management of the disease and to the development of treatment alternatives.

\section{RESUMO}

\section{Imunoativação e imunopatogenia durante leishmaniose visceral ativa}

A leishmaniose visceral é causada por protozoários do gênero do complexo Leishmania donovani. Durante a doença ativa no homem são detectados altos níveis de IFN- $\gamma$ e de TNF- $\alpha$ no soro, e elevada expressão de mRNA de IFN- $\gamma$ em amostras de órgãos linfóides sugerindo um estado intensamente ativado do sistema imunológico. A visão atual, no entanto, refere-se à imunossupressão específica aos antígenos de Leishmania com base em estudos utilizando células mononucleares do sangue periférico; a explicação para sua resposta deficiente seria provavelmente porque os linfócitos compometidos com antígeno de Leishmania são sequestrados nos órgãos linfóides. Para permitir a proliferação do parasito, citocinas desativadoras IL-10 e TGF- $\beta$ atuariam nos macrófagos, bem como os anticorpos anti-Leishmania opsonizando amastigotas e induzindo a produção IL-10 pelos macrófagos. Estes processos de intensa ativação e desativação provavelmente ocorreriam no baço e fígado, principalmente, e confirmados com amostras de órgãos. No entanto, analisando dados seqüenciais obtidos na leishmaniose visceral no hamster, sugerese provável presença de fatores fora do sistema imunológico como responsável pela inativação inicial de sintase induzível do óxido nítrico que ocorre antes da expressão de citocinas desativadoras. Na leishmaniose visceral ativa o sistema imunológico participa ativamente na lesão de órgãos não linfóides. Contrária à visão existente que considera somente mecanismos de deposição de imunocomplexos, observa-se na patogenia a participação de macrófagos, células T, citocinas e imunoglobulinas por mecanismo alternativo. 


\section{ACKNOWLEDGMENTS}

Studies were supported by FAPESP, CAPES, CNPq, FINEP and LIM/38-HC FMUSP.

\section{REFERENCES}

1. ANSARI, N.A.; SALUJA, S. \& SALOTRA, P. - Elevated levels of interferon-gamma, interleukin-10, and interleukin-6 during active disease in Indian kala azar. Clin. Immunol., 119: 339-345, 2006.

2. BABALOO, Z.; KAYE, P.M. \& ESLAMI, M.B. - Interleukin-13 in Iranian patients with visceral leishmaniasis: relationship to other Th2 and Th1 cytokines. Trans. roy. Soc. trop. Med. Hyg., 95: 85-88, 2001

3. BACELLAR, O.; BRODSKYN, C.; GUERREIRO, J. et al. - Interleukin-12 restore interferon-gamma production and cytotoxic responses in visceral leishmaniasis. J. infect. Dis., 173: 1515-1518, 1996.

4. BADARO, R.; JONES, T.C.; CARVALHO, E.M. et al. - New perspectives on a subclinical form of visceral leishmaniasis. J. infect. Dis., 154: 1003-1011, 1986.

5. BARRAL, A.; CARVALHO, E.M.; BADARO, R. \& BARRAL-NETTO, M. - Suppression of lymphocyte proliferative responses by sera from patients with American viscera leishmaniasis. Amer. J. trop. Med. Hyg., 35: 735-742, 1986

6. BARRAL-NETTO, M.; BARRAL, A.; BROWNELL, C.E. et al. - Transforming growth factor-beta in leishmanial infection: a parasite escape mechanism. Science, 257 $545-548,1992$

7. BELKAID, Y.; HOFFMANN, K.F.; MENDEZ, S. et al. - The role of interleukin (IL)-10 in the persistence of Leishmania major in the skin after healing and the therapeutic potential of anti-IL-10 receptor antibody for sterile cure. J. exp. Med., 194: 14971506, 2001.

8. BONVENTRE, J.V. \& COLVIN, R.B. - Adhesion molecules in renal disease. Curr. Opin Nephrol. Hypertens., 5: 254-261, 1996.

9. CALDAS, A.; FAVALI, C.; AQUINO, D. et al. - Balance of IL-10 and interferon-gamma plasma levels in human visceral leishmaniasis: implications in the pathogenesis. BMC infect. Dis., 5: 113, 2005.

10. CARVALHO, E.M.; BACELLAR, O.; BARRAL, A.; BADARO, R. \& JOHNSON Jr., W.D. - Antigen-specific immunosuppression in visceral leishmaniasis is cell mediated. J. clin. Invest., 83: 860-864, 1989.

11. CARVALHO, E.M.; BACELLAR, O.; BROWNELL, C. et al. - Restoration of IFN-gamma production and lymphocyte proliferation in visceral leishmaniasis. J. Immunol., 152: 5949-5956, 1994.

12. CARVALHO, E.M.; BADARO, R.; REED, S.G.; JONES, T.C. \& JOHNSON Jr., W.D. - Absence of gamma interferon and interleukin 2 production during active visceral leishmaniasis. J. clin. Invest., 76: 2066-2069, 1985.

13. CARVALHO, E.M.; TEIXEIRA, R.S. \& JOHNSON Jr., W.D. - Cell-mediated immunity in American visceral leishmaniasis: reversible immunosuppression during acute infection. Infect. Immun., 33: 498-500, 1981.

14. CILLARI, E.; LIEW, F.Y.; LO CAMPO, P. et al. - Suppression of IL-2 production by cryopreserved peripheral blood mononuclear cells from patients with active viscera leishmaniasis in Sicily. J. Immunol., 140: 2721-2726, 1988.

15. CILLARI, E.; VITALE, G.; ARCOLEO, F. et al. - In vivo and in vitro cytokine profiles and mononuclear cell subsets in Sicilian patients with active visceral leishmaniasis. Cytokine, 7: 740-745, 1995.

16. COSTA, F.A.; GOTO, H.; SALDANHA, L.C. et al. - Histopathologic patterns of nephropathy in naturally acquired canine visceral leishmaniasis. Vet. Path., 40: 677-684, 2003
17. COSTA, F.A.; GUERRA, J.L.; SILVA, S.M. et al. - CD4(+) T cells participate in the nephropathy of canine visceral leishmaniasis. Braz. J. med. biol. Res., 33: 14551458,2000

18. DAVIES, C.R. \& MAZLOUMI GAVGANI, A.S. - Age, acquired immunity and the risk of visceral leishmaniasis: a prospective study in Iran. Parasitology, 119: 247-257, 1999.

19. DE BRITO, T.; HOSHINO-SHIMIZU, S.; NETO, V.A.; DUARTE, I.S. \& PENNA, D.O. - Glomerular involvement in human kala-azar. A light, immunofluorescent, and electron microscopic study based on kidney biopsies. Amer. J. trop. Med. Hyg., 24 9-18, 1975.

20. DE MEDEIROS, I.M.; CASTELO, A. \& SALOMAO, R. - Presence of circulating levels of interferon-gamma, interleukin-10 and tumor necrosis factor-alpha in patients with visceral leishmaniasis. Rev. Inst. Med. trop. S. Paulo, 40: 31-34, 1998.

21. DUARTE, M.I.; DA MATTA, V.L.; CORBETT, C.E. et al. - Interstitial pneumonitis in human visceral leishmaniasis. Trans. roy. Soc. trop. Med. Hyg., 83: 73-76, 1989.

22. DUARTE, M.I.; SILVA, M.R.; GOTO, H.; NICODEMO, E.L. \& AMATO NETO, V - Interstitial nephritis in human kala-azar. Trans. roy. Soc. trop. Med. Hyg., 77: 531-537, 1983.

23. DUARTE, M.I.S. - Leishmaniose visceral. In: BRASILEIRO FILHO, G., ed. Bogliolo Patologia. 7. ed. Rio de Janeiro, Guanabara-Koogan, 2006. p. 1367-1372.

24. DUTRA, M.; MARTINELLI, R.; DE CARVALHO, E.M. et al. - Renal involvement in visceral leishmaniasis. Amer. J. Kidney Dis., 6: 22-27, 1985.

25. GALVAO-CASTRO, B.; SA FERREIRA, J.A.; MARZOCHI, K.F. et al. - Polyclonal B cell activation, circulating immune complexes and autoimmunity in human American visceral leishmaniasis. Clin. exp. Immunol., 56: 58-66, 1984.

26. GANTT, K.R.; SCHULTZ-CHERRY, S.; RODRIGUEZ, N. et al. - Activation of TGFbeta by Leishmania chagasi: importance for parasite survival in macrophages. J. Immunol., 170: 2613-2620, 2003.

27. GHALIB, H.W.; PIUVEZAM, M.R.; SKEIKY, Y.A. et al. - Interleukin 10 production correlates with pathology in human Leishmania donovani infections. J. clin. Invest., 92: 324-329, 1993.

28. GHALIB, H.W.; WHITTLE, J.A.; KUBIN, M. et al. - IL-12 enhances Th1-type responses in human Leishmania donovani infections. J. Immunol., 154: 4623-4629, 1995.

29. GHOSE, A.C.; HALDAR, J.P.; PAL, S.C.; MISHRA, B.P. \& MISHRA, K.K. Phytohaemagglutinin-induced lymphocyte transformation test in Indian kala-azar. Trans. roy. Soc. trop. Med. Hyg., 73: 725-726, 1979.

30. GOTO, H. \& LINDOSO, J.A. - Immunity and immunosuppression in experimental visceral leishmaniasis. Braz. J. med. biol. Res., 37: 615-623, 2004.

31. HAILU, A.; VAN BAARLE, D.; KNOL, G.J. et al. - T cell subset and cytokine profiles in human visceral leishmaniasis during active and asymptomatic or sub-clinical infection with Leishmania donovani. Clin. Immunol., 117: 182-191, 2005.

32. HAILU, A.; VAN DER POLL, T.; BERHE, N. \& KAGER, P.A. - Elevated plasma levels of interferon (IFN)-gamma, IFN-gamma inducing cytokines, and IFN-gamma inducible CXC chemokines in visceral leishmaniasis. Amer. J. trop. Med. Hyg., 71: 561-567, 2004

33. HALDAR, J.P.; GHOSE, S.; SAHA, K.C. \& GHOSE, A.C. - Cell-mediated immune response in Indian kala-azar and post-kala-azar dermal leishmaniasis. Infect. Immun. 42: 702-707, 1983.

34. HO, M.; KOECH, D.K.; IHA, D.W. \& BRYCESON, A.D. - Immunosuppression in Kenyan visceral leishmaniasis. Clin. exp. Immunol., 51: 207-214, 1983

35. KANE, M.M. \& MOSSER, D.M. - The role of IL-10 in promoting disease progression in leishmaniasis. J. Immunol., 166: 1141-1147, 2001 
36. KARP, C.L.; EL-SAFI, S.H.; WYNN, T.A. et al. - In vivo cytokine profiles in patients with kala-azar. Marked elevation of both interleukin-10 and interferon-gamma. J. clin. Invest., 91: 1644-1648, 1993.

37. KAYE, P.M.; SVENSSON, M.; ATO, M. et al. - The immunopathology of experimental visceral leishmaniasis. Immunol. Rev., 201: 239-253, 2004.

38. KENNEY, R.T.; SACKS, D.L.; GAM, A.A.; MURRAY, H.W. \& SUNDAR, S. - Splenic cytokine responses in Indian kala-azar before and after treatment. J. infect. Dis., 177: 815-818, 1998

39. KUMAR, R.; PAI, K. \& SUNDAR, S. - Reactive oxygen intermediates, nitrite and IFNgamma in Indian visceral leishmaniasis. Clin. exp. Immunol., 124: 262-265, 2001.

40. KURKJIAN, K.M.; MAHMUTOVIC, A.J.; KELLAR, K.L. et al. - Multiplex analysis of circulating cytokines in the sera of patients with different clinical forms of visceral leishmaniasis. Cytometry A, 69: 353-358, 2006.

41. LI, J.; HUNTER, C.A. \& FARRELL, J.P. - Anti-TGF-beta treatment promotes rapid healing of Leishmania major infection in mice by enhancing in vivo nitric oxide production. J. Immunol., 162: 974-979, 1999.

42. MANSON-BAHR, P.E. - Immunity in kala-azar. Trans. roy. Soc. trop. Med. Hyg., 55: $550-555,1961$

43. MATHIAS, R.; COSTA, F.A. \& GOTO, H. - Detection of immunoglobulin G in the lung and liver of hamsters with visceral leishmaniasis. Braz. J. med. biol. Res., 34: $539-543,2001$

44. MAURICIO, I.L.; GAUNT, M.W.; STOTHARD, J.R. \& MILES, M.A. - Genetic typing and phylogeny of the Leishmania donovani complex by restriction analysis of PCR amplified gp63 intergenic regions. Parasitology, 122: 393-403, 2001.

45. MELBY, P.C.; CHANDRASEKAR, B.; ZHAO, W. \& COE, J.E. - The hamster as a model of human visceral leishmaniasis: progressive disease and impaired generation of nitric oxide in the face of a prominent Th1-like cytokine response. J. Immunol., 166: 1912-1920, 2001.

46. MELBY, P.C.; TABARES, A.; RESTREPO, B.I. et al. - Leishmania donovani: evolution and architecture of the splenic cellular immune response related to control of infection. Exp. Parasit., 99: 17-25, 2001.

47. MILES, S.A.; CONRAD, S.M.; ALVES, R.G.; JERONIMO, S.M. \& MOSSER, D.M. A role for $\mathrm{IgG}$ immune complexes during infection with the intracellular pathogen Leishmania. J. exp. Med., 201: 747-754, 2005.

48. MINISTÉRIO DA SAÚDE. BRASIL. 2009. http://portal.saude.gov.br/PORTAL/arquivos/ pdf/leish_visceral_serie_2006.pdf.

49. MURPHY, M.L.; WILLE, U.; VILLEGAS, E.N.; HUNTER, C.A. \& FARRELL, J.P. - IL10 mediates susceptibility to Leishmania donovani infection. Europ. J. Immunol., 31: 2848-2856, 2001

50. NYLEN, S.; MAURYA, R.; EIDSMO, L. et al. - Splenic accumulation of IL-10 mRNA in $\mathrm{T}$ cells distinct from CD4+CD25+ (Foxp3) regulatory T cells in human visceral leishmaniasis. J. exp. Med., 204: 805-817, 2007.

51. NYLEN, S. \& SACKS, D. - Interleukin-10 and the pathogenesis of human visceral leishmaniasis. Trends Immunol., 28: 378-384, 2007.

52. PERUHYPE-MAGALHAES, V.; MARTINS-FILHO, O.A.; PRATA, A.; SILVA, L. DE A. \& RABELLO, A. et al. - Mixed inflammatory/regulatory cytokine profile marked by simultaneous raise of interferon-gamma and interleukin-10 and low frequency of tumour necrosis factor-alpha(+) monocytes are hallmarks of active human visceral Leishmaniasis due to Leishmania chagasi infection. Clin. exp. Immunol., 146: 124-132, 2006

53. POLI, A.; ABRAMO, F.; MANCIANTI, F. et al. - Renal involvement in canine leishmaniasis. A light-microscopic, immunohistochemical and electron-microscopic study. Nephron, 57: 444-452, 1991.
54. PRIANTI, M.G.; YOKOO, M.; SALDANHA, L.C.; COSTA, F.A. \& GOTO, H. Leishmania (Leishmania) chagasi-infected mice as a model for the study of glomerular lesions in visceral leishmaniasis. Braz. J. med. biol. Res., 40: 819-823, 2007.

55. PRIANTI, M.G.; SIGNORE, F. \& GOTO, H. - T cells and immunoglobulins participate in the pathogenesis of glomerulonephritis in experimental visceral leishmaniasis. In INTERNATIONAL CONGRESS OF IMMUNOLOGY, 13 ${ }^{\text {th }}$. Rio de Janeiro, 2007.

56. SACKS, D. \& NOBEN-TRAUTH, N. - The immunology of susceptibility and resistance to Leishmania major in mice. Nature Rev. Immunol., 2: 845-858, 2002.

57. SARTORI, A.; DE OLIVEIRA, A.V.; ROQUE-BARREIRA, M.C.; ROSSI, M.A. \& CAMPOS-NETO, A. - Immune complex glomerulonephritis in experimental kalaazar. Paras. Immunol., 9: 93-103, 1987.

58. SARTORI, A.; ROQUE-BARREIRA, M.C.; COE, J. \& CAMPOS-NETO, A. Immune complex glomerulonephritis in experimental kala-azar. II. Detection and characterization of parasite antigens and antibodies eluted from kidneys of Leishmania donovani-infected hamsters. Clin. exp. Immunol., 87: 386-392, 1992.

59. SEIXAS DUARTE, M.I.; TUON, F.F.; PAGLIARI, C.; KAUFFMAN, M.R. \& BRASIL, R.A. - Human visceral leishmaniasis expresses Th1 pattern in situ liver lesions. J. Infect., 57: 332-337, 2008.

60. SHAW, J.J. - Further thoughts on the use of the name Leishmania (Leishmania) infantum chagasi for the aetiological agent of American visceral leishmaniasis. Mem. Inst. Oswaldo Cruz, 101: 577-579, 2006

61. SMELT, S.C.; COTTERELL, S.E.; ENGWERDA, C.R. \& KAYE, P.M. - B cell-deficien mice are highly resistant to Leishmania donovani infection, but develop neutrophilmediated tissue pathology. J. Immunol., 164: 3681-3688, 2000.

62. SOMANNA, A.; MUNDODI, V. \& GEDAMU, L. - Functional analysis of cathepsin B-like cysteine proteases from Leishmania donovani complex. Evidence for the activation of latent transforming growth factor beta. J. biol. Chem., 277: 25305-25312, 2002.

63. SUNDAR, S.; REED, S.G.; SHARMA, S.; MEHROTRA, A. \& MURRAY, H.W. Circulating Thelper 1 (Th1) cell- and Th2 cell-associated cytokines in Indian patients with visceral leishmaniasis. Amer. J. trop. Med. Hyg., 56: 522-525, 1997.

64. TUON, F.F.; GUEDES, F.; FERNANDES, E.R. et al. - In situ immune responses to interstitial pneumonitis in human visceral leishmaniasis. Paras. Immunol., 31: 98 $103,2009$.

65. VAN ALDERWEGEN, I.E.; BRUIJN, J.A. \& DE HEER, E. - T cell subsets in immunologically-mediated glomerulonephritis. Histol. Histopath., 12: 241-250, 1997.

66. VENDRAME, C.M.; CARVALHO, M.D.; RIOS, F.J. et al. - Effect of insulin-like growth factor-I on Leishmania amazonensis promastigote arginase activation and reciproca inhibition of NOS2 pathway in macrophage in vitro. Scand. J. Immunol., 66: $287-$ 296, 2007.

67. VERESS, B.; OMER, A.; SATIR, A.A. \& EL HASSAN, A.M. - Morphology of the spleen and lymph nodes in fatal visceral leishmaniasis. Immunology, 33: 605-610, 1977.

68. WORLD HEALTH ORGANIZATION - Leishmaniasis. Magnitude of the problem 2009 http://www.who.int/leishmaniasis/burden/magnitude/burden_magnitude/en/index. html.

69. ZWINGENBERGER, K.; HARMS, G.; PEDROSA, C. et al. - Determinants of the immune response in visceral leishmaniasis: evidence for predominance of endogenous interleukin 4 over interferon-gamma production. Clin. Immunol. Immunopath., 57: 242-249, 1990

70. ZWINGENBERGER, K.; HARMS, G.; PEDROSA, C. et al. - Generation of cytokines in human visceral leishmaniasis: dissociation of endogenous TNF-alpha and IL-1 beta production. Immunobiology, 183: 125-132, 1991.

Received: 6 June 2009

Accepted: 15 July 2009 